\title{
Strategi Eksternal Public Relations dalam Membangun Citra Perusahaan
}

\author{
Deasy Crisnatalin $\mathbf{H}$ \\ Program Studi Ilmu Komunikasi Fakultas Ilmu Sosial Ilmu Politik \\ Universitas Pembangunan Nasional "Veteran" Yogyakarta \\ Jalan Babarsari No2 Tambakbayan Yogyakarta 55282, Telp. (0274) 485268
}

\begin{abstract}
Along with the increase in provisioning needs of the workforce preparation for high school and college, CIM instances as professional career development institute said such opposition. During its development, CIM instances can not be separated from efforts to form a company positive image. Because a positive image will always be attached to and affect long life for CIM own institutions. For it takes effort and the role of public relations, this research titled Strategic Analysis of the External Public Relations in Indonesia Cristal Institutions in Building Corporate Image Management. While the formulation of the problem in this research: How is the analysis of external public relations strategy in Indonesia Cristal Management agencies in building the company's image? This research uses qualitative research methods of descriptive paper describing a situation or event. For data collection techniques was conducted by interview and documentation. Research Report contains data excerpts to illustrate the presentation of the report. Researchers analyzed the data on the writing of this report. The result of this research is Public Relations agencies CIM using two-way communication process or effective communication with multiple steps of doing fact-gathering through surveys and research, planning and program using the promotional and publicity strategy, short and long term planning, action and communication by doing activities operations such as: seminars, workshops, media visits, and social visits and evaluations conducted by measuring the results that have been accomplished according to standards that have been formulated also create indicators of success of a program and SWOT analysis. So that shows that with a limited budget in a public relations agency CIM can be said is quite successful in building corporate image by looking at the number of interest-public interest and the Unfulfilled targets that have been defined from the programs offered by agencies CIM superior. Keywords: Strategic; External Public Relations; Image
\end{abstract}

\begin{abstract}
Abstrak
Seiring dengan meningkatnya kebutuhan penyediaan tenaga kerja persiapan untuk sekolah tinggi dan perguruan tinggi, CIM contoh sebagai lembaga pengembangan karir profesional mengatakan oposisi tersebut. Selama pengembangannya, instans CIM tidak lepas dari upaya membentuk citra positif perusahaan. Karena citra positif akan selalu melekat dan mempengaruhi umur panjang bagi lembaga CIM sendiri. Untuk itu dibutuhkan usaha dan peran humas, penelitian ini berjudul Strategi Eksternal Public Relations dalam Membangun Citra Perusahaan. Sedangkan perumusan masalah dalam penelitian ini adalah bagaimana analisis strategi hubungan masyarakat eksternal di lembaga Manajemen Cristal Indonesia dalam membangun citra perusahaan? Penelitian ini menggunakan metode penelitian kualitatif deskriptif yang menggambarkan situasi atau peristiwa. Untuk teknik pengumpulan data dilakukan dengan wawancara dan dokumentasi. Laporan Penelitian berisi kutipan data untuk menggambarkan presentasi laporan. Para peneliti menganalisis data pada penulisan laporan ini. Hasil penelitian ini adalah lembaga Humas CIM menggunakan proses komunikasi dua arah atau komunikasi yang efektif dengan beberapa langkah melakukan pengumpulan fakta melalui survei dan penelitian, perencanaan dan program menggunakan strategi promosi dan publisitas, perencanaan jangka pendek dan panjang, tindakan dan komunikasi dengan melakukan kegiatan operasi seperti: seminar, lokakarya, kunjungan media, dan kunjungan sosial dan evaluasi yang dilakukan dengan mengukur hasil yang telah dicapai sesuai dengan standar yang telah dirumuskan juga menciptakan indikator keberhasilan program dan analisis SWOT. Sehingga menunjukkan bahwa dengan keterbatasan anggaran di biro humas CIM dapat dikatakan cukup berhasil dalam membangun citra perusahaan dengan melihat jumlah kepentingan publik dan target yang belum terpenuhi yang telah ditetapkan dari program yang ditawarkan oleh lembaga CIM unggul. Kata kunci: Strategis; Hubungan Masyarakat Eksternal; Citra
\end{abstract}




\section{Pendahuluan}

Dewasa ini potret kualitas SDM kita masih sangat memprihatinkan. Pengangguran semakin tinggi terbuka, seperti halnya pengangguran terdidik sangat besar. Menurut Kompas Februari 2008, pengangguran terbuka (S1, D3, D2, D1) mencapai 740.000); yang setengah pengangguran (S1, D3, D2, D1) mencapai 1,4 juta. Daya saing relatif rendah, dan kondisi daya saing Indonesia pada urutan ke-69 dari 104 negara yang diteliti WorldEconomicForum 2004 (Bapeda DIY,2010).

Pembangunan di sektor dunia pendidikan di Indonesia sangat memprihatinkan, hal ini bukan hanya tanggung jawab pemerintah saja, tetapi setiap orang berperan untuk mewujudkan meningkatkan kualitas hidup masyarakat. Mahalnya biaya pendidikan tidak diikuti dengan peningkatan kualitas karena banyak pihak di negara ini menempatkan pendidikan sebagai suatu komoditas yang memiliki nilai jual tinggi. Banyak pihak mengejar pendidikan dari sisi kuantitas, sehingga menimbulkan berbagai macam konsekuensi logis seperti terabaikannya faktorkualitas pendidikannya serta banyak lulusan pendidikan formal tidak memiliki spesifikasi keahlian yang dibutuhkan oleh dunia kerja.

Seiring pesatnya kemajuan teknologi dan tingginya tuntutan spesifikasi dalam dunia kerja, menjadikan berkembangnya beberapa instansi pendidikan non formal di Yogyakarta. Instasi pendidikan non formal tersebut meliputi lembaga pendidikan di bidang soft skill, pengembangan keterampilan dan keahlian professional, bahasa, juga perhotelan. Di sini instansi pendidikan non formal menjawab sebuah tantangan yang sangat besar untuk menciptakan generasi muda yang kreatif, inovatif, serta memiliki daya saing yang tinggi ketika meraih masa depan dunia kerja.

Saat ini persaingan dalam instansi pendidikan non formal sangat kompetitif. Penulis melihat hal ini dari sisi banyaknya perkembangan instansi pendidikan non formal yang hadir di Yogyakarta. Adapun pesaing dari instansi Cristal Indonesia Manajemen (CIM) yakni, Kapilawastu dan John Powell (Lembaga Pengembangan Kepribadian). Setiap instansi pendidikan non formal mempunyai visi dan misi, juga keunggulan dari program-program yang mereka miliki. Semua lulusan dibekali dengan ilmu, serta membekali sikap kemandirian yang mendorong terciptanya kesempatan berwirausaha dan dapat menciptakan lapangan kerja. Ini merupakan salah satu bentuk dari citra perusahaan yang tujuannya adalah menginformasikan kepada publik dan memperoleh pelanggan. Dalam hal ini, citra perusahaan sangat penting untuk berlangsungnya suatu perusahaan tersebut.

Dalam upaya untuk membentuk citra perusahaan, diperlukan usaha dan peranan public relations. Dimana posisi public relations sangat tepat dalam mewakili perusahaan tersebut. PR merupakan profesi yang menjadi mediator antara lembaga yang diwakilinya dengan para publik baik eksternal maupun internal.

Menurut Dozier dan Broom dalam (Ruslan, 2002 : 22 - 23), "peranan public relations ada empat kategori diantaranya : sebagai penasehat ahli (expert prescriber), fasilitator komunikasi (communication fasilitator), fasilitator proses pemecahan masalah (problem solving process fasilitator), dan teknisi komunikasi (communication technician)" Peranan-peranan diatas bisa dijadikan sebagai bahan pedoman untuk menyukseskan program-program yang sedang dilakukan serta sebagai bekal untuk meningkatkan kinerja public relations.

Sebagai contoh dalam penelitian ini, penulis melakukan penelitian di suatu instansi pendidikan non formal yaitu Cristal Indonesia Manajemen (CIM). Seiring dengan meningkatnya kebutuhan pembekalan persiapan dunia kerja bagi sekolah maupun Perguruan Tinggi, Cristal Indonesia Manajemen (CIM) sebagai lembaga pengembangan karier professional menjawab tantangan tersebut. Kehadiran Cristal Indonesia Manajemen (CIM) merupakan wahana baru sebagai tempat pembelajaran bagi mahasiswa dan mahasiswi di Yogyakarta, yang ingin 
menambah pengalaman dan wawasan dalam bidang soft skill yang tidak diperoleh dibangku kuliah. Di samping menggali potensi diri dalam bidang entrepreneurship melalui aktivitas - aktivitas kreatif yang bernilai ekonomis.

Dalam program Cristal Indonesia Manajemen (CIM) terdapat fasilitas yang sangat mendukung peserta magang. Ini tidak lain karena instansi Cristal Indonesia Manajemen (CIM) memberikan posisi kerja sekaligus pelatihan dalam bidang front office, customer service relations, public relations, marketing development, broadcasting, stock exchange leadership, bahkan assistant manager. Program yang ditawarkan instansi Cristal Indonesia Manajemen (CIM) sangat fleksibel, peserta bisa melakukan secara part time maupun full time sehingga dapat memilih. Kehadiran CIM melalui beragam kegiatannya, seperti Kuliah Magang Kerja (KMK), Penyiar, Entrepreneurship, serta Jogja Stock Club diharapkan akan menjadi laboratorium efektif bagi mahasiswa atau mahasiswi yang ingin membekali diri dengan pengalaman kerja sebagai bekal untuk menerjuni dunia kerja professional sesungguhnya. Instansi CIM juga telah meluluskan alumni peserta magang KMK (Kuliah Magang Kerja) sebanyak \pm 500 orang, peserta magang SPJ (Sekolah Penyiar Jogja) \pm 100 orang, dan masing-masing alumni peserta magang KMK (Kuliah Magang Kerja) berkerja di sebagian instansi di swasta maupun BUMN di sekitar Jateng serta sebagian berdikari menjadi entrepreneurship, lalu alumni peserta magang dari program SPJ (Sekolah Penyiar Jogja) juga sebagian bekerjadiradio-radiolokaldiYogyakarta, (data base alumni instansi CIM ada di lampiran).

Menumbuhkembangkan citra positif perusahaan (corporate image) terhadap publik ekstenal atau masyarakat luas demi tercapainya pengertian bagi kedua belah pihak termasuk salah satu peran marketing public relations (Kurniasari dkk, 2008). Di sini instansi Cristal Indonesia Manajemen (CIM) mencitrakan perusahaannya sebagai instansi yang bertujuan untuk menciptakan generasi muda yang kreatif, inovatif dan penuh motivasi dalam meraih masa depannya. Salah satu ciri khas dari instansi Cristal Indonesia Manajemen (CIM) adalah sebagai lembaga yang bergerak dalam bidang soft skill (pendidikan pengembangan keterampilan dan keahlian) dengan menyediakan program-program keahlian berprilaku baik, terampil, kreatif, berbakat dan berkualitas dalam membentuk pribadi yang unggul. Dan keunikan dari instansi Cristal Indonesia Manajemen (CIM) adalah memberikan kehangatan atau suasana kekeluargaan kepada para peserta magang baik dari para trainer juga para tim manajemen CIM sendiri. Bagi Cristal Indonesia Manajemen (CIM), citra adalah tujuan utama yang hendak diraih selain itu citra juga merupakan prestasi yang hendak dicapai. Citra tersebut hanya dapat diukur melalui penilaian, pandangan, dan tanggapan baik (positif) atau buruk (negatif) yang berasal dari publik yang menjadi sasaran bagi Cristal Indonesia Manajemen (CIM) dan masyarakat luas. Instansi pendidikan non formal seperti Cristal Indonesia Manajemen (CIM) dalam perkembangannya tidak pernah terlepas dari upaya membentuk citra positif perusahaan, karena citra yang positif akan selalu melekat dan mempengaruhi nama instansi itu sendiri. Upaya-upaya dalam membentuk citra positif suatu instansi Cristal Indonesia Manajemen (CIM) membutuhkan strategi public relations. Menanamkan citra positif suatu instansi di hati masyarakat pengguna jasa merupakan faktor penting dalam persaingan perusahaan, yang dapat menentukan sukses atau tidaknya penjualan jasa pendidikan non formal tersebut. Untuk itu public relations di instansi Cristal Indonesia Manajemen (CIM) harus pandai-pandai dalam membuat kebijakan dan keputusan untuk kelangsungan hidup instansi Cristal Indonesia Manajemen (CIM) dimasa yang akan datang. Fungsi public relations instansi Cristal Indonesia Manajemen (CIM) adalah melaksanakan dan mengkoordinasikan segala 
kegiatan penerangan, hubungan konsumen instansi Cristal Indonesia Manajemen (CIM), masyarakat, media, dan pemerintah, membuat perencanaan stratejik meliputi pengembangan dan penanganan masalah-masalah komunikasi dan pelayanan pelanggan (customer service) di instansi untuk mencapai visi dan misi instansi Cristal Indonesia Manajemen (CIM) dan menciptakan citra positif perusahaan.

Oleh karena itu hubungan dengan publik diluar perusahaan merupakan keharusan yang mutlak, dan perusahaan tidak mungkin berdiri sendiri tanpa bekerja sama dengan perusahaan yang lain. Untuk itu instansi Cristal Indonesia Manajemen (CIM) harus menciptakan hubungan yang harmonis dengan publik-publik khususnya dan masyarakat umumnya. Salah satunya dengan melakukan komunikasi dengan publik eksternal secara informatif dan persuasif. Informasi yang disampaikan hendaknya jujur, teliti dan sempurna berdasarkan fakta yang sebenarnya. Pemanfaatan public relations sangat berpotensi besar dalam untuk membangun citra positif perusahaan. Public Relations di instansi Cristal Indonesia Manajemen (CIM) terus mengembangkan program-program keterampilan dan keahlian serta melakukan promosi agar citra instansi Cristal Indonesia Manajemen (CIM) melekat di benak masyarakat. Lalu harus mampu mengkomunikasikan kebijakan-kebijakan yang diberikan manajemen perusahaan secara jelas kepada publik dan sekaligus mampu menyerap aspirasi dankeinginan publik terhadapperusahaan.

Perkembangan public relations mempunyai hubungan yang erat sekali dengan kemajuankemajuan dalam masyarakat di berbagai bidang, khususnya pendidikan formal dan non formal. Dalam hal ini profesi public relations dirasakan perlu kehadirannya. Kebutuhan akan keberadaan public relations dalam suatu organisasi, merupakan salah satu elemen yang menentukan kelangsungan suatu organisasi secara positif. Public Relations adalah bentuk komunikasi yang terencana, baik itu ke dalam maupun ke luar, antar suatu organisasi dengan semua khalayaknya dalam rangka mencapai tujuan-tujuan spesifik yang berlandaskan pada saling pengertian (Jefkins, 2003:10).

Menurut pakar Humas Internasional, Cutlip \& Center, and Canfield dalam (Ruslan, 2007: 19) fungsi public relations dapat dirumuskan sebagai berikut, 1. Menunjang aktifitas utama manajemen dalam mencapai tujuan bersama; 2. Membina hubungan yang harmonis antara organisasi dengan publiknya yang merupakan khalayak sasarannya; 3. Mengidentifikasi segala sesuatu yang berkaitan dengan opini, persepsi, dan tanggapan masyarakat terhadap organisasi yang diwakilinya, atau sebaliknya; 4. Melayani keinginan publiknya dan memberikan sumbang saran kepada pimpinan manajemen demi tujuan dan manfaat bersama; 5. Menciptakan komunikasi dua arah timbal balik, mengatur arus informasi, publikasi serta pesan dari organisasi ke publiknya atau sebaliknya, demi tercapainya citra positif bagi kedua belah pihak (Ruslan, 2007:19).

Sedangkan peran public relations dalam suatu perusahaan selain sebagai pengambil keputusan sehingga dekat dengan top manajemen, juga harus mau bekerjasama dan berhubungan dengan semua bagian yang ada dalam organisasi atau perusahaanyang bersangkutan. Tanpapemahaman dan dukungan aktif dari bagian lain kegiatan public relations tidak akan berhasil dengan baik.

Dapat disimpulkan bahwa kegiatan kehumasan saat ini memang diperlukan di berbagai perusahaan besar atau kecil, organisasi dengan massa yang banyak maupun sedikit. Kegiatan humas tidak bisa dilepaskan dari usaha untuk membangun citra perusahaan. Public Relations berkaitan erat dengan citra (image). Citra merupakan tujuan utama yang hendak diraih selain itu citra juga merupakan prestasi yang hendak dicapai. Citra tersebut hanya dapat di ukur melalui penilaian, pandangan, dan tanggapan baik (positif) atau buruk (negatif) yang berasal dari publik yang menjadi sasaran bagi instansi Cristal Indonesia Manajemen 
(CIM) dan masyarakat luas. Dalam hal ini instansi Cristal Indonesia Manajemen (CIM) mencitrakan perusahaannya sebagai instansi yang bertujuan untuk menciptakan generasi muda yang kreatif, inovatif dan penuh motivasi dalam meraih masa depannya. Untuk membangun citra perusahaan, diperlukan strategi public relations.

Hakikatnya strategi adalah perencanaan dan manajemen untuk mencapai tujuan tertentu dalam praktik operasionalnya. Strategi digunakan untuk melakukan komunikasi kepada publik agar mendapatkan perhatian atau dukungan yang lebih dari publiknya, sedangkan strategi yang efektif adalah sebagai berikut, 1. Bagaimana mengubah sikap (how to change the attitude); 2. Mengubah opini (to change the opinion); 3. Mengubah perilaku (to change behavior) (Ruslan, 2002:31).

Public relations memerlukan strategi komunikasi yang tepat dalam menciptakan citra positif secara efektif. Berusaha memperkenalkan produknya kepada publik sehingga harus dapat mempengaruhi serta membujuk sasaran yang dituju. Sasaran yang hendak dituju adalah publik, jadi perusahaan berusaha membangun citra (image) positif agar publik dapat selalu percaya terhadap perusahan tersebut sehingga keberlangsungan perusahaan dapat terjaga.

Oleh karena itu hubungan dengan publik diluar perusahaan merupakan keharusan yang mutlak. Karena perusahaan tidak mungkin berdiri sendiri tanpa bekerja sama dengan perusahaan yang lain. Karena itu instansi Cristal Indonesia Manajemen (CIM) harus menciptakan hubungan yang harmonis dengan publik-publik khususnya dan masyarakat umumnya. Salah satunya dengan melakukan komunikasi dengan publik eksternal secara informatif dan persuasif. Informasi yang disampaikan hendaknya jujur, teliti dan sempurna berdasarkan fakta yang sebenarnya.

Strategi perencanaan yang dilakukan public relations ini kemudian di implementasikan dalam sebuah kegiatan yang bersifat eksternal, maksudnya kegiatan yang akan dilakukan berhubungan dengan publik. Peran public relations disini yaitu untuk mencoba memenuhi keinginan publik terhadap suatu instansi atau lembaga pendidikan tersebut. Sehingga akan terjadi suatu hubungan yang positif antara publik dengan instansi tersebut. Atau secara singkat dapat digambarkan sebagai berikut:

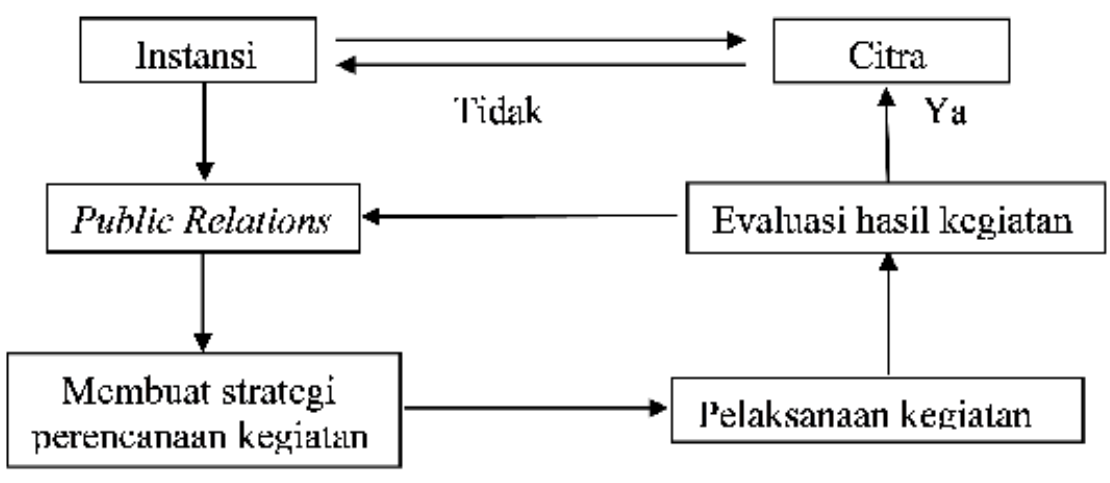

Gambar 1. Kerangka Pemikiran Penulis dalam Penelitian ini 
Gambar konsep kerangka pemikiran ini dapat dikatakan sebagai ringkasan dari teori kerangka pemikiran penelitian. Dari gambar diatas dapat dijelaskan bahwa public relations yang bekerja didalam suatu instansi pasti akan berusaha membuat supaya instansi tersebut memiliki citra yang positif di mata publik, dengan cara membuat dan merencanakan strategi baru dalam suatu bentuk kegiatan yang ditujukan bagi masyarakat (kegiataneksternal). Strategiperencanaankegiatan tersebut kemudian diimplementasikan bagi masyarakat kemudian akan di evaluasi hasilnya.

Apabila evaluasi dari kegiatan tersebut tidak berhasil maka strategi yang direncanakan public relation belum tepat mengenai sasarannya, akan tetapi dapat dikatakan berhasil apabila kegiatan dan tujuan yang diinginkan dapat tercapai, dalam arti strategi tersebut efektif. Apabila strategi dalam perencanaan yang di implementasikan berhasil maka publik akan menilai dan memberi tanggapan positif terhadap instansi tersebut, sehingga kepercayaan publik terhadap instansi tersebut akan terus terjaga. Citra positif yang diberikan publik terhadap suatu instansi akan berhubungan terhadap keberlangsungan instansi tersebut.

Untuk itu proses evaluasi merupakan tahap penting dalam strategi public relations yang dilakukan oleh perusahaan. Dalam evaluasi program public relations, perusahaaan melakukan sebuah analisis mengenai situasi di sekitar perusahaan. Keseluruhan evaluasi terdiri dari kekuatan, kelemahan, peluang, dan ancaman yang dinamakan analisa SWOT (Strength,Weakness, Opportunity, Threats). Pengertian SWOT artinya kita mencoba menjadikan kelemahan menjadi kekuatan dan ancaman menjadi kesempatan atau peluang. Maksudnya adalah mengidentifikasi berbagai faktor secara sistematis untuk merumuskan strategi suatu organisasi. Setelah perusahaan membuat SWOT, perusahaan akan dapat mengembangkan sasaran spesifik untuk suatu periode perencanaan.

Berkaitan dengan kerangka pemikiran diatas tersebut, penelitian ini di dukung dengan teori komunikasi "planning theory". Planning theory menjelaskan tentang proses yang dilakukan seseorang dalam merencanakan tingkah laku, terutama tingkah laku dalam berkomunikasi yang dilakukan untuk mencapai suatu tujuan tertentu. Sebelum melaksanakan kegiatankegiatan sebagai upaya untuk mencapai suatu tujuan tertentu, diperlukan perencanaan yang menjadi dasar dilaksanakannya suatu kegiatan (Little John, 1998:21). Pada tahap penyusunan kebijakan sebagai upaya memperkenalkan dan membangun citra di instansi Cristal Indonesia Manajemen (CIM), public relations di instansi Cristal Indonesia Manajemen (CIM) menyusun rangkaian kegiatan yang bertujuan untuk mengetahui keinginan publik terhadap intansi Cristal Indonesia Manajemen (CIM).

Untuk dapat menjalankan kebijakankebijakan yang ditetapkan dalam rangka membangun citra positif dari instansi Cristal Indonesia Manajemen (CIM), public relations melakukan kegiatan ekternal dengan bentuk menggunakan media massa dalam proses sosialisasi kepada masyarakat yang menjadi target instansi perusahaan. Berbagai kebijakan dalam rangka membangun citra perusahaan diharapkan mampu merubah cara pandang publik terhadap perusahaan, kebijakan utama ditekankan pada kualitas pelayanan jasa pendidikan non formal melalui programprogram pengembangan keterampilan dan keahlian yang ditawarkan. Kebijakan-kebijakan yang ditetapkan public relations dalam upaya membangun citra perusahaan Cristal Indonesia Manajemen (CIM) diharapkan mampu membawa perubahan pada citra instansi tersebut. Sehingga citra positif di instansi Cristal Indonesia Manajemen (CIM) melekat di benak masyarakat.

\section{Metode Penelitian}

Penelitian ini menggunakan metode penelitian kualitatif. Metode penelitian kualitatif adalah penelitian yang bermaksud untuk memahami fenomena tentang apa yang dialami 
oleh subjek penelitian, misalnya perilaku, persepsi, motivasi, tindakan, dll dan dengan menggunakan cara deskripsi dalam bentuk katakata dan bahasa, pada suatu konteks khusus yang alamiah dan dengan memanfaatkan berbagai metode alamiah (Moleong, 2007:6).

Peneliti menggunakan metode penelitian kualitatif karena dalam meneliti bidang ilmu sosial, dan khususnya komunikasi adalah lebih tepat jika mengunakan metode kualitatif agar lebih mengetahui fenomenafebomena tentang aspek kejiwaan, perilaku, sifat, tanggapan, opini, perasaan, keinginan dan kemauan seseorang atau kelompok.

Dengan menggunakan metode ini, akan didapatkan gambaran tentang bagaimana analisis strategi eksternal public relations di instansi Cristal Indonesia Manajemen (CIM) dalam membangun citra perusahaan. Maka risetnya dilaksanakan dengan teknik-teknik wawancara secara mendalam terhadap suatu peristiwa atau kejadian, perilaku atau sikap tertentu dengan upaya mendekati informan (responden) yang bersangkutan dengan objek penelitian kualitatif

Jenis penelitian yang digunakan adalah deskriptif. Penelitian deskriptif kualitatif merupakan penelitian yang tidak mencari atau menjelaskan hubungan, tidak menguji hipotesis atau membuat prediksi (Rakhmat,1991 :25). Jenis penelitian data yang dikumpulkan adalah berupa kata-kata, gambar, dan bukan angka-angka. Hal itu disebabkan oleh adanya penerapan metode kualitatif.

Selain itu, semua yang dikumpulkan berkemungkinan menjadi kunci terhadap apa yang sudah diteliti. Dengan demikian, laporan penelitian akan berisi kutipan-kutipan data untuk memberi gambaran penyajian laporan tersebut. Data tersebut berasal dari wawancara, catatan lapangan,foto,dokumenpribadi,maupundokumen resmi lainnya. Pada penulisan laporan, peneliti menganalisis data tersebut (Moleong, 2007 : 11).

Objek dalam penelitian ini adalah: Analisis strategi eksternal public relations di instansi
Cristal Indonesia Manajemen (CIM) dalam membangun citra perusahaan. Data Primer ialah data yang diperoleh secara langsung dari sumbernya, kemudian diamati dan dicatat. Data primer dalam penelitian ini diperoleh dari hasil wawancara dengan narasumber dan hasil observasi dari kegiatan eksternal public relations instansi CIM. a) Narasumber. Pada penelitian kualitatif narasumber mempunyai peranan yang sangat penting bagi peneliti karena narasumber memiliki informasi yang dibutuhkan bagi peneliti. Narasumber tidak hanya memberikan tanggapan seperti apa yang dikehendaki peneliti, tetapi ia bisa memilih informasi yang tepat bagi diteliti. Maka yang menjadi narasumber dalam penelitian ini dan diwawancarai adalah, 1. Public Relations instansi CIM; 2. CEO instansi CIM; 3. Mahasiswa/i yang mengikuti program pelatihan di instansi CIM; b) Observasi peristiwa. Dalam penelitian sebuah data atau informasi juga dapat diperoleh dari peristiwa, aktivitas atau prilaku yang berkaitan dengan sasaran penelitian. Hal ini dikarenakan pada setiap peristiwa dan aktivitas mengandung banyak informasi yang dibutuhkan oleh peneliti. Oleh karena itu sebuah peristiwa menjadi sangat penting bagi seorang peneliti

Data Sekunder, adalah data yang diperoleh dari pihak lain secara tidak langsung, yang berasal dari sumber lain diluar objek penelitiannya baik literatur, buku-buku, website, maupun informasi-informasi dari bagian Public Relations yang menunjang penelitian.

Dalam penelitian ini peneliti akan menggunakan metode pengumpulan data serta analisis data. Metode pengumpulan data yang akan dipakai dalam penelitian ini adalah sebagai berikut, Pertama, wawancara, merupakan bentuk komunikasi antara dua orang yang melibatkan seseorang ingin memperoleh informasi dari seseorang lainnya dengan mengajukan pertanyaan-pertanyaan berdasarkan tujuan tertentu. Wawancara dilakukan untuk mendapatkan informasi yang menyangkut permasalahan yang diteliti. Dalam melakukan 
wawancara dilakukan teknik interview guide yang merupakan cek list atas data-data atau isu yang ingin diungkap atau ditemukan dari sebuah daftar pertanyaan. Dalam interview guide tidak ada urutan logis untuk pertanyaan karena pada prinsipnya, pertanyaan akan berkembang seiring dengan jawaban informan. Pertanyaan mengikuti respon informan dan pedoman wawancara dapat berubah dalam setiap wawancara, disesuaikan dengan kebutuhan dan kondisi saat wawancara. Adapun informan terdiri dari, a) Yeti Kartikasari, selaku Public Relations instansi CIM; b) Risma Kesumanendra, selaku CEO instansi CIM; c) Theresa. S, selaku peserta mengikuti program pelatihan di instansi CIM.

Kedua, observasi, teknik observasi dipakai ketika penulis menghadapi secara langsung suatu kejadian dimana penulis berada secara fisik di tempat kejadian kemudian menginterpretasikan kejadian tersebut. Melakukan pengamatan secara cermat dan sistematis di lokasi penelitian guna memperoleh gambaran tentang fenomena yang dicermati. Observasi ini dilakukan dengan cara observasi tidak langsung (non participant). Observasi tidak langsung (non participant) adalah observasi yang dilakukan tidak secara langsung tetapi dengan melakukan wawancara untuk meminta kesaksian dan keterangan dari orang lain yang mengamati langsung kejadian tersebut seperti Public Relations, CEO instansi CIM dan Mahasiswa/i yang mengikuti program pelatihan di instansi CIM.

Ketiga, dokumentasi, merupakan alat pengumpul data dengan menggunakan dokumen sebagai sumber data, karena dalam banyak hal dokumen sebagai sumber data yang dimanfaatkan untuk menguji, menafsirkan, bahkan untuk meramalkan. Informasi diperoleh dari datadata, pendapat, maupun catatan yang dimiliki instansi CIM, seperti dokumentasi pribadi, berita acara, dokumen resmi, foto dan sejenisnya yang mendukung kerangka pemikiran tersebut.

Menggunakan jenis analisis data interactive model of analysis. Menurut Sutopo (1998 : 15), dalam model ini ada tiga komponen pokok dalam analisis interaktif yaitu : data reductions, data display, dan conclusion drawing. Data reductions merupakan seleksi pemfokusan, penyederhanaan, dan abstraksi data kasar yang ada di lapangan. Proses reduksi data ini berlangsung terus menerus selama pelaksanaan penelitian sampai laporan.

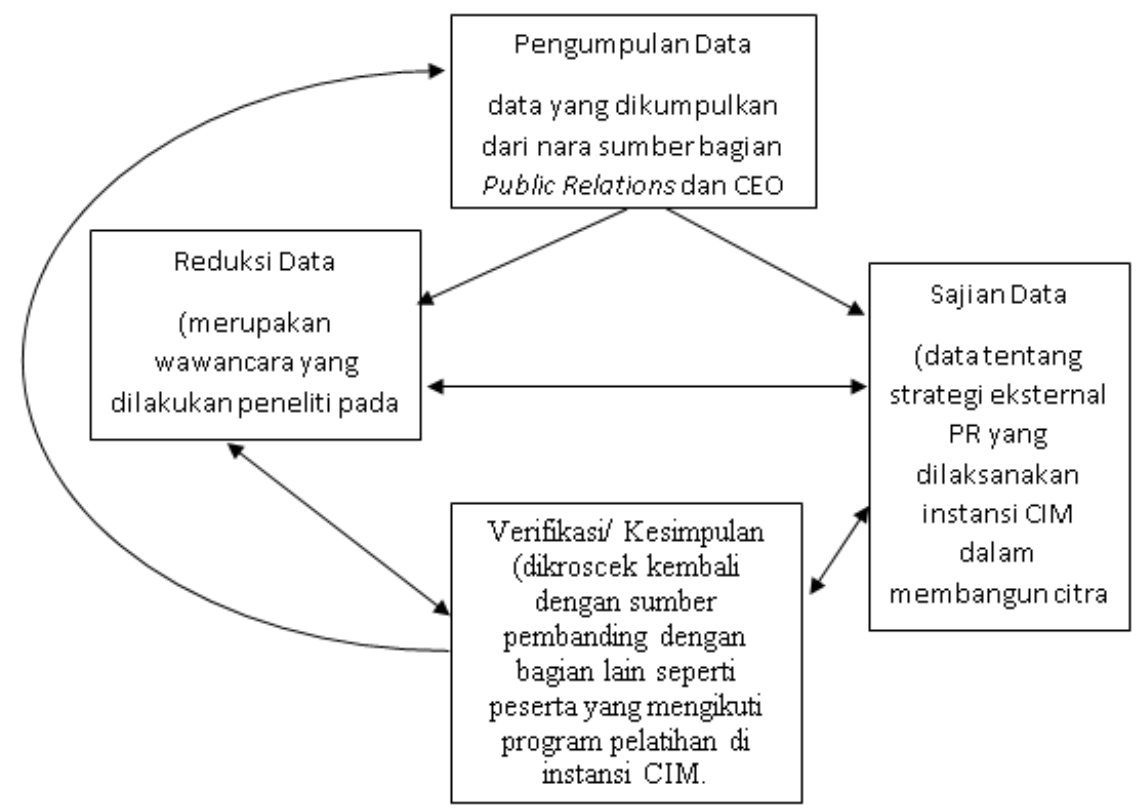

Gambar 3.1. Model Analisis Interaktif

Sumber : Diadaptasi melalui Sutopo, (2002 : 96) 
Data display merupakan suatu rakitan organisasi informasi yang memungkinkan kesimpulan data yang dilakukan. Peneliti merakit informasi-informasi yang telah diperoleh selama penelitian untuk mempermudah dalam penarikan kesimpulan. Conclision drawing yaitu suatu penarikan kesimpulan atau verifikasi dari hasil penelitian. Berikut nerupakan gambar model Analisis Interaktif

Pada penelitian data yang dikumpulkan dari nara sumber bagian Public Relations dan CEO instansi CIM akan di kroscek dengan sumber pembanding dengan bagian lain seperti peserta yang mengikuti program pelatihan di instansi CIM sebagai verifikasi data. Dari langkah reduksi data ini kemudian data di verifikasi untuk disajikan dalam suatu kesimpulan lalu dijadikan suatu sajian data untuk mendapatkan kepuasan tentang strategi eksternal PR yang dilaksanakan instansi CIM dalam membangun citra perusahaan sehingga citra yang sudah dibangun dapat melekat dan tertanam di benak publiknya CIM, yakni Mahasiswa/i PTN/PTS, Pelajar, Pengajar PTN/ PTS, PengajarSMU/SMK, danMasyarakatumum.

Penelitian ini menggunakan teknik validitas data dengan teknik triangulasi sumber. Triangulasi adalah teknik pemeriksaan keabsahan data yang memanfaatkan sesuatu yang lain atau diluar data itu untuk keperluan pengecekan atau sebagai pembanding terhadap data itu. Teknik triangulasi sumber berarti membandingkan dan mengecek balik derajat kepercayaan suatu informasi yang diperoleh melalui waktu dan alat yang berbeda dalam penelitian kualitatif.

Hal itu dapat dicapai dengan jalan , 1. Membandingkan data hasil pengamatan dengan data hasil wawancara; 2. Membandingkan apa yang dikatakan orang di depan umum dengan apa yang dikatakannya secara pribadi; 3 . Membandingkan apa yang dikatakan orangorang tentang situasi penelitian dengan apa yang dikatakannyasepanjang waktu (Moleong, 2007 : 330); 4. Membandingkan keadaan dan perspektif seseorang dengan berbagai pendapat dan pandangan orang seperti masyarakat, orang berpendidikan, atau orang pemerintahan; 5. Membandingkan hasil wawancara dengan isi suatu dokumen yang berkaitan

Hasil perbandingan yang didapat tidak selalu memiliki kesamaan pendapat, pandangan, atau pemikiran karena yang terpenting adalah bisa mengetahui adanya perbedaan-perbedaan tersebut. Penggunaan teknik triangulasi sumber pada penelitian ini dilakukan dengan cara memanfaatkan sumber yaitu pihak-pihak diluar peneliti yang akan memberikan pemaknaan terhadap strategi eksternal PR yang dilaksanakan instansi CIM dalam membangun citra perusahaan.

Setelah semua data hasil peneletian terkumpul, maka langkah selanjutnya adalah mengidentifikasi kevalidan data yang diperoleh oleh peneliti. Langkah-langkah yang dilakukan peneliti untuk memperoleh kevalidan data, yakni dengan, 1. Membandingkan data hasil pengamatan dengan data hasil wawancara; 2 . Data diperoleh melalui pengamatan dan wawancara. Berdasarkan wawancara yang peneliti lakukan dengan Public Relations instansi CIM, dapat diketahui data mengenai bagaimana analisis strategi eksternal public relations di instansi CIM dalam membangun citra perusahaan. Untuk mengecek lebih jauh, apa saja upaya yang dilakukan Public Relations instansi CIM dalam membangun citra perusahaan, maka peneliti juga melakukan wawancara, dan mendokumentasikan langsung di Bagian Public Relations instansi CIM. Membandingkan data hasil wawancara dengan berbagai pendapat dan pandangan orang seperti peserta yang mengikuti pelatihan di instansi CIM.

Untuk membandingkan data yang diperoleh peneliti saat wawancara dengan Public Relations instansi CIM, maka peneliti juga melakukan wawancara dengan peserta yang mengikuti pelatihan di instansi CIM. Hal ini untuk membandingkan apakah strategi eksternal di instansi CIM dalam membangun citra perusahaan melalui program-program pelatihan unggulan beserta fasilitas dan pelayanan yang diberikan 
selama ini telah memberikan dampak yang baik kepada publiknya CIM, yakni Mahasiswa/i PTN/PTS, Pelajar, Pengajar PTN/PTS, Pengajar SMU/SMK, dan Masyarakat umum.

Berdasarkan wawancara yang peneliti lakukan, hasil penelitian di halaman 93-95 menurut 3 orang konsumen yaitu Theresa Siregar (angkatan XVII program KMK), Robertus Sunarko (angkatan XVII program KMK), dan Widyaningrum (angkatan IV program SPJ) ini memberikan respon positif terhadap instansi CIM; 3. Membandingkan data hasil wawancara dengan isi suatu dokumen yang berkaitan. Langkah selanjutnya untuk mengetahui apakah data yang diperoleh peneliti benar atau tidak, maka peneliti membandingkan data hasil wawancara dengan isi suatu dokumen. Dari wawancara yang peneliti lakukan diperoleh data mengenai strategi eksternal Public Relations di instansi CIM dalam membangun citra perusahaan. Berikut merupakan penjelasan dalam membangun kepercayaan konsumen instansi CIM. Data tentang hubungan pencitraan dalam membangun kepercayaan konsumen diketahui melalui surat kabar, yaitu dengan penyusunan kliping. Lalu data yang sudah di kliping tersebut dijadikan arsip untuk pihak Public Relations dan diberikan kepada CEO instansi CIM agar bersama-sama mengevaluasi informasi yang telah disajikan tentang instansi CIM apakah baik atau perlu lakukan revisi buat kedepannya.

Untuk mengetahui apakah yang dilakukan Public Relations instansi CIM tersebut benar atau tidak, maka peneliti mencoba membandingkannya dengan isi suatu dokumen, dokumen yang digunakan yaitu press release, publikasi dan surat kerja sama dengan media yang digunakan oleh pihak instansi CIM, (dapat dilihat di lampiran).

Berdasarkan dari hasil wawancara yang peneliti lakukan, bahwa public relations di instansi CIM dapat dikatakan cukup berhasil dalam membangun citra perusahaan dengan melihat dari ketertarikan publiknya CIM dalam mengikuti program-program unggulan yang ditawarkan beserta fasilitas, pelayanan, sarana dan prasarana yang diberikan;

\section{Hasil Penelitian dan Pembahasan}

Dari hasil penelitian diatas, instansi CIM merupakan instansi yang bergerak dibidang jasa pendidikan yang memberikan pelatihan/ training pengembangan kepribadian atau soft skill. Maka faktor kenyamanan dan kepuasaan konsumen akan program-program unggulan yang ditawarkan beserta fasilitas dan pelayanan menjadi kunci utamanya. Sehingga perlu dijalankan peran public relations untuk menjaga hubungan dengan publik dan juga membangun citra perusahaan tersebut. Public Relations instansi CIM memiliki peran utama yang berkaitan dengan membangun citra perusahaan dengan publiknya.

Citra merupakan tujuan pokok dalam setiap perusahaan, pentingnya pemahaman citra dalam kegiatan public relations karena menyangkut profil perusahaan yang diwakilinya. Public Relations selalu menjaga hubungan dengan divisi lain yang ada di instansi CIM, karena adanya saling keterkaitan dan mendukung setiap pelaksanaan program dalam mencapai tujuan perusahaan. Setiapbagianmempunyaiperananmasing-masing dan berhubungan dengan bagian-bagian lain.

Dalam upaya membangun citra instansi CIM, Public Relations bekerja sama dengan instansiinstansi lain atau dengan publik eksternalnya. Karena instansi CIM tidak mungkin berdiri sendiri tanpa bekerja sama dengan perusahaan lain. Public Relations mempunyai peran yang sangat penting ketika berhubungan dengan pihak eksternalnya dengan pendekatan komunikasi yang terus menerus dalam mengadakan hubungan untuk mencapai suatu kerjasama. Komunikasi merupakan suatu mata rantai (link) yang menghubungkan berbagai komponen organisasi/ perusahaan dengan berbagai pihak baik yang di dalam maupun yang di luar perusahaan.

Berkaitan dengan kerangka pemikiran di atas tersebut, penelitian ini di- dukung dengan teori komunikasi "planning theory". Planning theory menjelaskan tentang proses yang dilakukan seseorang dalam merencanakan tingkah laku, terutama tingkah laku dalam berkomunikasi yang dilakukan untuk mencapai suatu tujuan tertentu. 
Sebelum melaksanakan kegiatan - kegiatan sebagai upaya untuk mencapai suatu tujuan tertentu. Diperlukan perencanaan yang menjadi dasar dilaksanakannya suatu kegiatan (Little John, 1998:21). Pada tahap penyusunan kebijakan sebagai upaya memperkenalkan dan membangun citra di instansi CIM, public relations di instansi CIM menyusun rangkaian kegiatan yang bertujuan untuk mengetahui keinginan publik terhadap instansi CIM. Untuk dapat menjalankan kebijakan-kebijakan yang ditetapkan dalam rangka membangun citra positif dari instansi CIM, public relations melakukan kegiatan ekternal dengan bentuk menggunakan media massa dalam proses sosialisasi kepada masyarakat yang menjadi target instansi perusahaan. Berbagai kebijakan dalam rangka membangun citra perusahaan diharapkan mampu merubah cara pandang publik terhadap perusahaan, kebijakan utama ditekankan pada kualitas pelayanan jasa pendidikan non formal melalui program-program pengembangan keterampilan dan keahlian yang ditawarkan. Kebijakankebijakan yang ditetapkan public relations dalam upaya membangun citra perusahaan CIM diharapkan mampu membawa perubahan pada citra instansi tersebut. Sehingga citra positif di instansi CIM melekat di benak masyarakat.

Untuk itu perencanaan penting dilakukan agar kegiatan dapat berjalan lancar dan target yang direncanakan dari kegiatan tersebut dapat tercapai. Dalam menjalankan sebuah program kegiatan, public relations instansi CIM menggunakan proses komunikasi dua arah atau komunikasi efektif yang memiliki beberapa tahapan yakni melakukan RAPCE (Research, Action Planning, Communication, and Evaluation), pengumpulan fakta, definisi permasalahan, perencanaan dan program, aksi dan komunikasi, serta evaluasi.

Adapun uraian lebih jelas mengenai proses komunikasi dua arah atau komunikasi efektif yang dilakukan public relations instansi CIM dalam membangun citra perusahaan sebagai berikut, pertama, pengumpulan fakta atau definisi permasalahan yang dilakukan oleh public relations instansi CIM adalah, a) Mengetahui terlebih dahulu apa yang di butuhkan oleh publik instansi CIM, lalu melakukan survey dan riset agar strategi yang dilakukan tepat sasaran sesuai dengan tujuan yang ingin dicapai oleh perusahaan. Dalam merencanakan sebuah produk, perusahaan selalu menyesuaikan dengan target segmen pasarnya instansi Cristal Indonesia Manajemen (CIM); b) Melakukan proses segmentasi, dari proses segmentasi yang dilakukan nantinya dapat diambil suatu target konsumen yang paling potensial untuk dikembangkan. Proses segmentasi sangat penting untuk dilakukan karena proses ini berfungsi untuk memudahkan dan memfokuskan seorang public relations dalam mempromosikan produknya, dalam hal ini jasa pendidikan. Setiap perusahaan memiliki segmentasi yang berbeda - beda tergantung pada produk apa yang akan dikembangkan. Berdasarkan penelitian yang dilakukan pada divisi public relations instansi Cristal Indonesia Manajemen(CIM), segmen yang dibangun oleh instansi ini adalah Mahasiswa/i PTN/PTS, Sekolah Tinggi mulai semester I-akhir, pengajar PTN/PTS, pengajar SMU/ SMK, siswa-siswi SMU/SMK dan masyarakat umum yang ingin memperoleh pendidikan soft skill dan pengalaman dunia kerja; c) Berdasarkan survey dan riset kecil yang dilakukan oleh public relations instansi CIM, dikampus mahasiswa belum mendapatkan soft skill dalam persiapan dunia kerja. Sedangkan mahasiswa/i semester pertengahan dan akhir mulai membutuhkan persiapan untuk memasuki dunia kerja. Seperti bagaimana menulis $\mathrm{CV}$ dan lamaran kerja yang baik, bagaimana menghadapi job interview, bagaimana berpenampilan profesional;

Kedua, berdasarkan survey dan riset diatas, maka public relations instansi CIM membuat strategi dan perencanaan, berikut uraian dari strategi dan perencanaan yang di lakukan oleh public relations instansi CIM. 1. Strategi public relations di instansi CIM dalam membuat kegiatan eksternal untuk membangun citra 
perusahaannya dilakukan dengan berbagai upaya, yakni, a) Upaya Penampilan profesional CEO dan staf CIM ; Good performance dan excellent service dalam memberikan pelayanan serta pendampingan training dan pelatihan yang mengesankan bagi peserta; b) Melaksanakan strategi promosi secara efektif dan efisien serta mengemasnya secara menarik; Bekerjasama dengan organisasi kemahasiswaan di PTN/PTS melalui kegiatan talkshow, seminar, training untuk mahasiswa bertema persiapan memasuki dunia kerja; c) Publikasi secara rutin melalui media massa cetak mengenai aktivitas dan prestasi CIM maupun peserta; d) Mewadahi alumni program pelatihan di CIM dengan pembentukan klub eksekutif muda dengan beragam aktivitas; Diskusi dunia kerja, outbound dan talkshow; 2. Strategi perencanaan yang dilakukan oleh Public Relations Instansi CIM meliputi perencanaan jangka panjang dan jangka pendek, a) Secara kongkrit, rencana jangka panjang dirumuskan dalam bentuk rencana event. Pelatihan, talkshow dan workshop, kunjungan media, outbound, dan expo. CIM memiliki kalender pendidikan untuk mempermudah dalam perencanaan kegiatan, yang disesuaikan dengan kalender pendidikan yang berlaku di Jogja pada khususnya; b) Sedangkan rencana jangka pendek, meliputi kegiatan pelatihan rutin yang menjadi program utama CIM, seperti workshop Kuliah Magang Kerja, pelatihan penyiar dan reporter, dan table manner; 3. Aksi dan Komunikasi, setelah rencana disusun dengan sebaik-baiknya sebagai hasil dari pemikiran yang matang berdasarkan faktafakta/data yang telah dikumpulkan, kemudian dilakukan kegiatan operasional. Dalam hal ini implementasi kegiatan yang akan dilakukan oleh public relations instansi CIM dengan melakukan kegiatan eksternal meliputi, a) Seminar dan workshop soft skill dan broadcasting bekerjasama dengan organisasi kemahasiswaan di PTN/PTS di Jogja. (Ada piagam kerjasama). Serta menjalin kerjasama dengan salah satu toko buku di Jogja untuk kegiatan talkshow, b) Bekerjasama dengan perusahaan untuk memberikan kesempatan magang peserta kuliah magang kerja (KMK) CIM. Menerjunkan peserta menjadi asisten supervisor di Pameran Pangan Nasional, JEC, 2008 bekerjasama dengan salah satu franchise di Jogja. c) Kegiatan lain; Media visit secara rutin ke sejumlah media cetak di Jogjakarta sebagai upaya untuk menjalin kerjasama dan bagian dari publikasi kelembagaan; d) Secara rutin CIM juga melakukan kegiatan sosial ke sejumlah panti sosial; 4. Evaluasi yang dilakukan oleh public relations instansi CIM adalah, a) Hasil yang sudah dicapai akan diukur sesuai dengan standar yang telah dirumuskan sebelumnya; b) Public Relations CIM biasanya membuat indikatorindikator kesuksesan dari suatu kegiatan. Apabila keseluruhan point indikator sesuai dengan apa yang sudah dirumuskan berarti menandakan, bahwa kegiatan yang telah berlangsung dapat dikatakan sukses; c) Public relations CIM melakukan sebuah analisis mengenai situasi di sekitar perusahaan. Keseluruhan evaluasi terdiri dari kekuatan, kelemahan, peluang, dan ancaman yang dinamakan analisis SWOT.

Berdasarkan uraian strategi public relations dalam membuat kegiatan eksternal di instansi CIM untuk membangun citra perusahaan diatas dari hasil pembahasan penelitian menurut 3 orang konsumen yaitu Theresa Siregar (angkatan XVII program KMK), Robertus Sunarko (angkatan XVII program KMK), dan Widyaningrum (angkatan IV program SPJ) ini diperoleh bahwa public relations di instansi CIM dapat dikatakan cukup berhasil dalam membangun citra perusahaan dengan melihat banyaknya animoanimo masyarakat dan terpenuhnya target yang sudah ditetapkan dari program-program unggulan yang ditawarkan instansi CIM. Instansi CIM juga telah meluluskan alumni peserta magang Kuliah Magang Kerja (KMK) sebanyak \pm 500 orang, peserta magang SPJ \pm 100 orang, dan masingmasing alumni peserta magang Kuliah Magang Kerja (KMK) berkerja di sebagian instansi di swasta maupun BUMN di sekitar jateng serta 
berdikari menjadi entrepreneurship, lalu alumni peserta magang dari program SPJ juga sebagian bekerja di radio-radio lokal di yogyakarta, (data base alumni instansi CIM ada di lampiran).

Alasannya karena sesungguhnya, CIM didirikan bukan dengan modal materi yang besar. Sehingga ketika merumuskan program kerja, selalu diupayakan untuk tidak beranggaran besar. Begitu pula di divisi Public Relations, dengan budget terbatas diupayakan agar semua program CIM saling berkaitan dan berkesinambungan serta mampu membawa efek yang besar bagi kemajuan instansi CIM.

\section{Simpulan}

Berdasarkan hasil penelitian dan pembahasan mengenai Analisis Strategi Eksternal Public Relations di Instansi Cristal Indonesia Manajemen (CIM) dalam Membangun Citra Perusahaan ini mempunyai kesimpulan sebagai berikut, 1. Tugas/kegiatan utama yang harus dilakukan external public relations di instansi Cristal Indonesia Manajemen (CIM) seperti, a) Menjalin relasi dengan media baik cetak maupun elektronik. Melalui pengiriman rilis, talkshow radio, partisipan di salah satu stasiun $\mathrm{TV}$, media visit; b) Mengadakan koreksi dan saran kepada pimpinan perusahaan, terutama kegiatan yang mendapat sorotan atau kritikan publik; c) Berkoordinasi dengan CEO, Head Manager, Program Director, serta divisi terkait lainnya. Dengan selalu berusaha untuk menunjukkan citra perusahaan yang positif melalui komunikasi personal; d) Bertanggung jawab dalam up date promosi Cristal Indonesia Manajemen (CIM) secara keseluruhan melalui emai; e) Mengadakan penyelidikan atau penelitian tentang isue-isue pendidikan yang sedang berkembang yang akan dijadikan masukan untuk penyusunan program perusahaan; f) Menjalin kerjasama dengan BEM, HMJ PTN/PTS Jogjakarta; g) Bersinergi dengan perusahaan, toko buku untuk event; 2. Program kegiatan eksternal instansi CIM yang di lakukan public relations, yakni, a) Seminar dan workshop soft skill dan broadcasting bekerjasama dengan organisasi kemahasiswaan di PTN/PTS di Jogja, (ada piagam kerjasama) serta menjalin kerjasama dengan salah satu toko buku di Jogja untuk kegiatan talkshow; b) Bekerjasama dengan perusahaan untuk memberikan kesempatan magang peserta kuliah magang kerja (KMK) CIM; Menerjunkan peserta menjadi asisten supervisor di Pameran Pangan Nasional, JEC, 2008 bekerjasama dengan salah satu franchise di Jogja; c) Kegiatan lain; Media visit secara rutin ke sejumlah media cetak di Jogjakarta sebagai upaya untuk menjalin kerjasama dan bagian dari publikasi kelembagaan; d) Secara rutin CIM juga melakukan kegiatan sosial ke sejumlah panti sosial; 3. Penelitian ini menggunakan Planning Theory. Planning theory menjelaskan tentang proses yang dilakukan seseorang dalam merencanakan tingkah laku, terutama tingkah laku dalam berkomunikasi yang dilakukan untuk mencapai suatu tujuan tertentu. Sebelum melaksanakan kegiatan-kegiatan sebagai upaya untuk mencapai suatu tujuan tertentu, diperlukan perencanaan yang menjadi dasar dilaksanakannya suatu kegiatan (Little John, 1998:21). Untuk dapat menjalankan kebijakankebijakan yang ditetapkan dalam rangka membangun citra positif dari instansi CIM, public relations melakukan kegiatan ekternal dengan bentuk menggunakan media massa dalam proses sosialisasi kepada masyarakat yang menjadi target instansi perusahaan; 4. Proses evaluasi merupakan tahap penting dalam strategi eksternal public relations yang dilakukan oleh instansi CIM. Dalam melakukan evaluasi kegiatan eksternal public relations, instansi CIM melakukan suatu analisis mengenai situasi di sekitar perusahaan. Keseluruhan evaluasi terdiri dari kekuatan, kelemahan, peluang, dan ancaman yang dinamakan analisis SWOT (Strength, Weakness, Oppurtunity, Threat). 
Daftar Pustaka

Jefkins, Frank. (2003). Public Relations. Jakarta: Erlangga. Kurniasari, Atika, Puji Lestari, dan Isbandi Sutrisno. (2008). Strategi Marketing Public Relations PT. Telkom Kancatel Pati dalam Program "Flexi Door to Door" dan "Speedy Go to School" untuk Membangun Brand Awareness dan Brand Knowledge di Wilayah Pati. Jurnal Ilmu Komunikasi, 6(3), 228-241.
Rakhmat, Jallaludin. (1991). Metode Penelitian Komunikasi. Bandung: Remaja Rosdakarya. Rakhmat, Jallaludin. (1999). Psikologi Komunikasi. Bandung: Remaja Rosdakarya. Ruslan, Rosady. (2002). Kiat dan Strategi Public Relations. Jakarta: Raja Grafindo. Persada. Ruslan, Rosady. (2007). Manajemen Public Relations \& MediaKomunikasi KonsepsiDan Aplikasi. Jakarta: PT. Raja Grafindo Persada. Sutopo, HB. (1998). Metode Penelitian Komunikasi. Surakarta: UNS Pers. Sutopo, HB. (2002). Metode Penelitian Komunikasi. Surakarta: UNS Pers. 